\title{
Development of a Double Row Tractor Operated Yam Minisett Planter
}

\author{
A. K. Arkoh, E. Y. H. Bobobee, A. Addo
}

\begin{abstract}
Drudgery in manual yam minisett planting was identified as a major constraint facing yam cultivation in Ghana. The main objective of the study was to develop a double row yam minisett (DRYM) planter using Finite Element Analysis (FEA). A potato planter was adopted and modified to suit the design of DRYM planter. The main task was to perform $3 D$ modeling of the planter major components using FEA method. Analysis of systems (ANSYS) software was used for FEA. Minisett and soil physical properties were factored into the design processes. Total deformation and equivalent (Von-Mises) stress were $0.442 \mathrm{~mm}$ and $7.37 \mathrm{MPa}$ for hopper; $0.01 \mathrm{~mm}$ and $9.18 \mathrm{MPa}$ for ridger bottom and that of furrow opener were $1.8^{-0.6} \mathrm{~mm}$ and $6.27 \mathrm{MPa}$, respectively. Maximum total deformation and equivalent (Von-Mises) stress were below material specification of $50 \mathrm{~mm}$ and $250 \mathrm{MPa}$ for structural steel, and $20 \mathrm{~mm}$ and, $440 \mathrm{MPa}$ for mild steel, respectively. The study concluded that the entire design was within the material property and permissible stress limits of the materials used. Yam planter development will enhance farmer satisfaction.
\end{abstract}

Keywords: Finite element analysis, metering mechanism, manual planting, mechanised planting.

\section{INTRODUCTION}

$Y_{\text {am (Dioscorea spp.), a tuber crop originated from West }}$ Africa, where about $95 \%$ of yam production obtained [1]. Ghana was the second higher yam producer next to Nigeria (64.2\%) [1]. Ghana was leading by $94 \%$ of yam export from West Africa [2]. Despite several prospects in yam production, planting of yam is manual in Ghana and sub-Saharan Africa [3]. Manual planting according to [4] is extremely labour demanding, tedious and time-consuming. It also affects many practices such as plant spacing, depth and sett covering. Currently, the problem related with yam harvesting in Ghana is partly solved by Bosrotsi et al.[5] but planting of yam minisett still depends on traditional practices. To curb these challenges, there is the need to mechanize yam minisett planting. Planters have a key role to play in increasing crop productivity. To design a planter, crop physical properties were among factors considered.

Manuscript received on August 29, 2021.

Revised Manuscript received on September 20, 2021.

Manuscript published on October 30, 2021.

*Correspondence Author

A. K. Arkoh*, Automotive and Refrigeration Engineering, Takoradi Technical University, Takoradi, Ghana. Emai: albert.arkoh@ttu.edu.gh

E. Y. H. Bobobee, Agricultural and Biosystems Engineering, Kwame Nkrumah University of Science and Technology, Kumasi, Ghana. Email: Emmanuel.bobobee@gmail.com

A. Addo, Agricultural and Biosystems Engineering, Kwame Nkrumah University of Science and Technology, Kumasi, Ghana. Email: ahmaddo@gmail.com

(C) The Authors. Published by Blue Eyes Intelligence Engineering and Sciences Publication (BEIESP). This is an open access article under the CC BY-NC-ND license (http://creativecommons.org/licenses/by-nc-nd/4.0/)
Buitenwerf et al. [6] considered shape of potato, belt speeds, and number of cups for planter assessment. Again, Al-Gaadi and Marey [7], concluded that ground wheel speed, different seed sizes, and shapes affect the plant spacing. The objective of the study was to design and fabricate a double row yam minisett planter using Finite Element Analysis (FEA).

\section{METHODOLOGY}

\section{A. Yam minisett physical properties measurement}

To mechanize the planting of yam minisett, the potato planter was adopted and modified to suit the planting of yam minisett. The features of minisett (planting material) is a form of sector which has five (5) faces of about $80 \%$ fresh and remaining $20 \%$ skin [8], unlike potato planting material which has skin all round. Due to the nature of the sett, modification of potato planter included metering mechanism, positioning of hopper, furrow opener and coverer. Factors such as minisett and soil physical properties, angle of repose of the minisett were considered during the planter design.

Yam tubers of 82\% moisture content (wet base) acquired from Crop Research Institute (CRI) Kumasi, Ghana was sliced into an average size of $50 \mathrm{~g}$. Fig. 1 shows the sett size and device developed for the determination of the angle of repose. Fifty (50) setts were randomly selected for sett physical properties determination. The measurements included the arc length $(\mathrm{cm})$, thickness $(\mathrm{cm})$, radius $(\mathrm{cm})$, mass (g) as well as the angle of repose of the yam minisett. Arc length, thickness, and radius of the sett were taken by using venial caliper and meter rule. Electronic balance was used to measure the weight of the sett. The method of measuring the angle of repose was adopted from Awulu et al. [4].

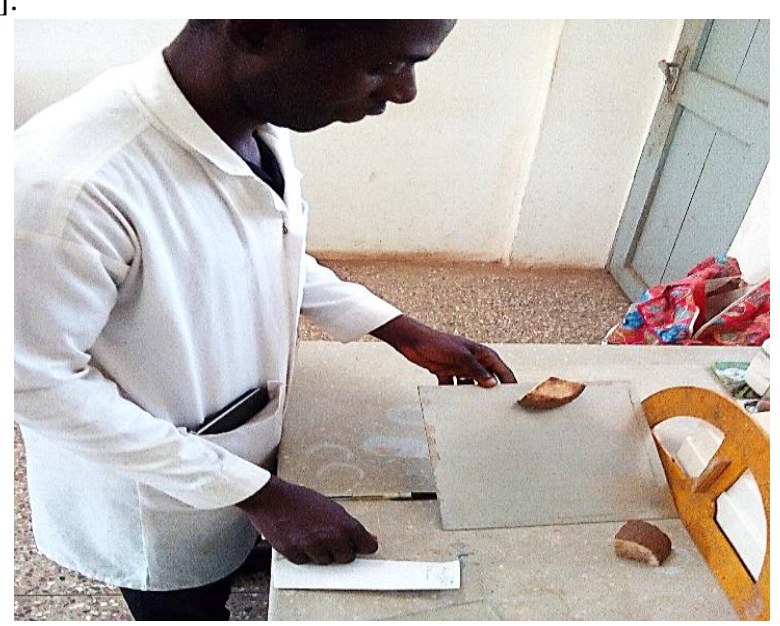

Fig.1: Angle of repose determination

Published By:

Blue Eyes Intelligence Engineering and Sciences Publication (BEIESP) 13 (C) Copyright: All rights reserved.

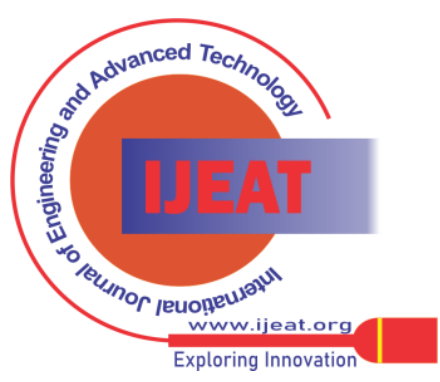


The method was modified by using a $2.5 \mathrm{~mm}$ mild steel plate inclined together with a graduated protractor. The yam sett was moved along the inclined material in relation to the graduated protractor and observed closely to see the angle at which the yam sett started to slide or rolls easily down the inclined structure. The angle at which set began to slide was recorded as the angle of repose for the yam sett.

\section{B. Design Principles and Requirement of the Planter}

The main features of a double-row mechanical yam minisett planter were the hopper, the metering mechanism, furrow opener, coverer, frame, and land wheels. The planter was designed to hitch to the three-point linkages of the tractor. Planter was ground-wheel driven to establish planter performance relative to tractor speed. The selection and design calculations of the planter components were based on materials specification, soil and yam physical properties. The design of yam minisett planter did not consider the orientation of sett from the hopper into the soil since results from Arkoh and Bobobee [8] confirmed that healthy sett germinates so far as soil touches the skin of the minisett. However, the following considerations were made:

1. The planter should be within the buying capacity of small-scale farmers who cultivate 1-4 acres of field.

2. The planter should be able to plant minisett sizes up to $80 \mathrm{~g}$ and different yam varieties.

3. Materials for the fabrication should be readily available.

4. The planter should have high planting capacity compared to manual planting

5. The planter must be able to work in sandy-loam soil

\section{Experimental setup and structural analysis}

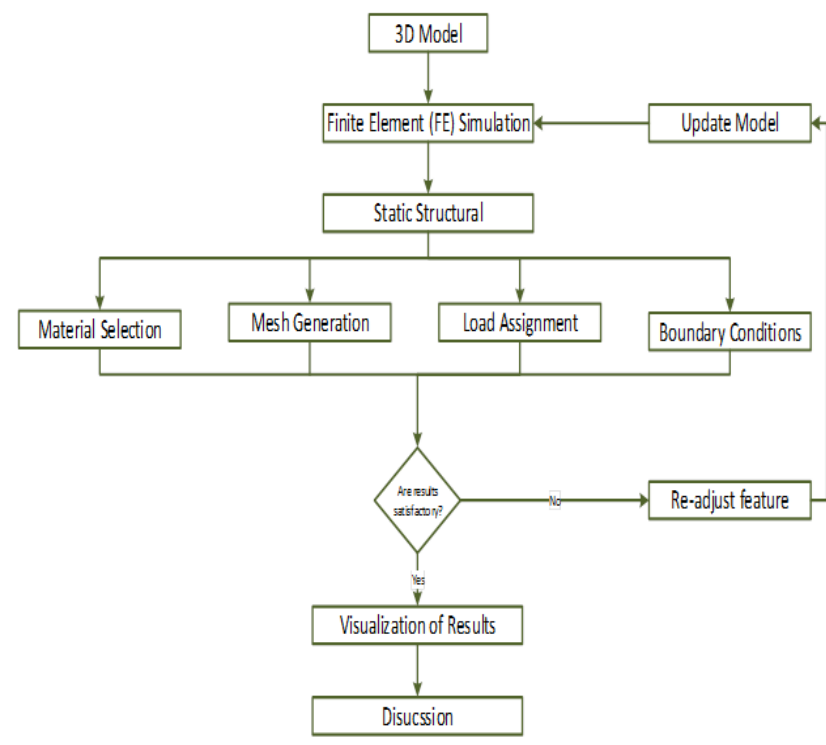

Fig 2: FEM simulation setup flow

Fig. 2 presents a FEM simulation setup flow chart for Double Row yam Minisett (DRYM) planter design processes. Data acquired from minisett, soil condition and field experiments were subjected to the planter designing. A three-dimensional geometric model of the planter assembly was created in Autodesk Inventor Professional

Computer-Aided Design software (CAD) and exported into the finite element software (ANSYS). ANSYS V.18 (a commercial finite element package) was used in the study. The high productivity computing (HPC) utilized in the study using a Workstation Server Computer at the KNUST Mechanical laboratory. Finite Element Analysis (FEA) method was used to study and predict the structural analysis of the bodies under static and dynamic loading conditions. The structural prediction of the planter was done through simulation to find the concentration of total deformation and Von-Mises (Equivalent) stress.

\section{Hopper design}

The hopper on the planter was, formed in a trapezoidal shape to ensure a free flow of setts by the assistance of gravitational force. The type of metering mechanism selected describes the design and position of the hopper. The angle of repose of the sett informed the vertical positioned $90^{\circ}$ to the horizontal and slope of the hopper was formed $68^{\circ}$ to the horizontal for easy flow of setts which conforms to the angle of repose of the sett determined. The material $2.5 \mathrm{~mm}$ thick mild steel (AISI 1018) was used for hopper design. equation (1, 2 and 3) was used for hopper design. Key considerations in the design of hopper were as follows:

- Weight of yam sett in the hopper, $\left(W_{y s}\right)$

- Bulk density of yam sett, $g / \mathrm{cm}^{3},\left(\gamma_{y s}\right)$

- The inner volume of hopper, $m m^{3},\left(V_{h}\right)$

- The volume of yam sett, $\mathrm{mm}^{3},\left(V_{y s}\right)$

- Number of yam sett, $(n)$

$$
\begin{aligned}
& V_{h}=111 V_{Y a} \\
& V_{w a}=W_{Y a} / V_{Y a} \\
& V_{h}=1,1 W_{w a} / V_{Y a}
\end{aligned}
$$

The total mass of sett and the inner volume was multiplied by a design factor of 1.1 to give the total load exerted on the hopper and volume of hopper respectively. Hence, the maximum weight of sett was utilized in the calculation. Hopper design dimensions includes top width of the hopper $100.0 \mathrm{~mm}$, bottom width $106 \mathrm{~mm}$, height $800 \mathrm{~mm}$, angle subtended by hopper $134.3^{0}$, volume (Actual) $\left(3.943 \mathrm{~m}^{3}\right)$ and volume (3D model $4.24 \mathrm{~m}^{3}$ ).

\section{E. Structural analysis of hopper}

Material specifications of mild steel AISI 1018 for the hopper was presented in Table 1. The selection of material was based on material engineering properties and availability. Boundary and loading conditions values considered for hopper loading setup includes number of yam sett 80 , maximum mass per sett ( $80 \mathrm{~g}$ ), total mass of sett 6400 $\mathrm{g}$ and total load of sett exerted on the hopper $7.04 \mathrm{~kg}(69.06$ N).

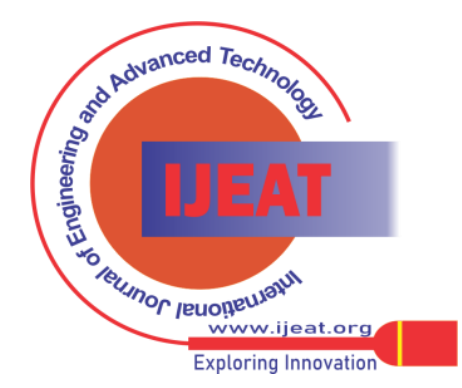


Table 1. Properties and material specifications of the hopper

\begin{tabular}{|c|c|c|c|c|c|c|c|}
\hline \multicolumn{2}{|c|}{ Mechanical Properties of Hopper Material } \\
\hline $\begin{array}{c}\text { Material and } \\
\text { composition }\end{array}$ & $\begin{array}{c}\text { Ultimate } \\
\text { tensile } \\
\text { strength } \\
\text { (MPa) }\end{array}$ & $\begin{array}{c}\text { Tensile } \\
\text { Yield } \\
\text { stress }\end{array}$ & $\begin{array}{c}\text { Bulk } \\
\text { Modulus }\end{array}$ & $\begin{array}{c}\text { Poisson } \\
\text { ratio }\end{array}$ & $\begin{array}{c}\text { Elongation at } \\
\text { break (in 50 } \\
\text { mm) }\end{array}$ & $\begin{array}{c}\text { Density } \\
\text { Modulus }\end{array}$ \\
\hline $\begin{array}{c}\text { AISI 1018 Mild } \\
\text { steel/Low } \\
\text { carbon steel }\end{array}$ & $440 \mathrm{MPa}$ & $370 \mathrm{MPa}$ & $140 \mathrm{GPa}$ & 0.290 & $15.0 \%$ & 7870 & $205 \mathrm{GPa}$ \\
$\mathrm{hg}^{2}$ & & & & & \\
\hline
\end{tabular}

Source: [9]

\section{F. Furrow opener and ridger bottom design}

The type of furrow opener adopted was ridger type which gives a ' $\mathrm{V}$ ' shape opening because of its cuts and transferring of soil sideways for easy planting [9]. The material used for the furrow opener and ridger bottom was $6 \mathrm{~mm}$ structural steel (A36) thick because of its strength and engineering property. Presented in Table 2 and 3 were material specifications used on the bases of the assumed soil, furrow opener and ridger bottom specification for the design. Predicted horizontal and vertical forces on planter were determined jointly by using modified General Soil Mechanics Equation (GSME) for blades and narrow tines concept and spreadsheet prepared by [11]. According to [12], the use of spreadsheets makes the calculation of draught and vertical forces of tine or mouldboard plough simple.

Table 2: Material specifications of furrow opener and ridger bottom

\begin{tabular}{|c|c|c|c|c|c|}
\hline \multirow[b]{2}{*}{ Material name } & \multicolumn{5}{|c|}{ Material Properties } \\
\hline & $\begin{array}{l}\text { Ultimate tensile } \\
\text { strength (MPa) }\end{array}$ & $\begin{array}{l}\text { Yield stress } \\
\text { (MPa) }\end{array}$ & $\begin{array}{l}\text { Bulk modulus } \\
\text { (GPa) }\end{array}$ & Poisson ratio & $\begin{array}{l}\text { Elongation at } \\
\text { break (in } 50 \mathrm{~mm} \text { ) }\end{array}$ \\
\hline A 36 Structural Steel & 450 & 250 & 200 & 0.26 & $10 \%$ \\
\hline
\end{tabular}

Table 3. Static structural analysis settings utilized in the study

\begin{tabular}{|c|c|c|c|}
\hline \multicolumn{4}{|c|}{ Static Structural analysis } \\
\hline & Hopper & Furrow Opener & Ridger Bottom \\
\hline Material & AISI 1018 Mild steel & A36 structural steel & A36 structural steel \\
\hline Loading Type & $\begin{array}{l}\text { Constant amplitude fully } \\
\text { reversed }\end{array}$ & $\begin{array}{l}\text { Constant amplitude fully } \\
\text { reversed }\end{array}$ & $\begin{array}{l}\text { Constant amplitude fully } \\
\text { reversed }\end{array}$ \\
\hline Mesh statistics & $\begin{array}{l}\text { Node: } 34395 \\
\text { Elements: } 16671\end{array}$ & $\begin{array}{l}\text { Node: } 3990 \\
\text { Elements: } 1750\end{array}$ & $\begin{array}{l}\text { Node: } 34395 \\
\text { Elements: } 16671\end{array}$ \\
\hline Stress components & $\begin{array}{l}\text { Von Misses Equivalent Stress } \\
\text { (Maximum Distortion Energy } \\
\text { criterion) }\end{array}$ & $\begin{array}{l}\text { Von Misses Equivalent Stress } \\
\text { (Maximum Distortion Energy } \\
\text { criterion) }\end{array}$ & $\begin{array}{l}\text { Von Misses Equivalent Stress } \\
\text { (Maximum Distortion Energy } \\
\text { criterion) }\end{array}$ \\
\hline Analysis Type & Linear elastic static structural & Linear elastic static structural & Linear elastic static structural \\
\hline Solver & Mechanical APDL & Mechanical APDL & Mechanical APDL \\
\hline Load & 69.0624 & $2.47 \mathrm{kN}$ & - \\
\hline $\begin{array}{l}\text { Temperature } \\
\text { Gravity }\end{array}$ & $\begin{array}{l}22^{\circ} \mathrm{C} \\
9.81 \mathrm{~ms}^{-2}\end{array}$ & $\begin{array}{l}22^{\circ} \mathrm{C} \\
9.81 \mathrm{~ms}^{-2}\end{array}$ & $\begin{array}{l}22^{\circ} \mathrm{C} \\
9.81 \mathrm{~ms}^{-2}\end{array}$ \\
\hline
\end{tabular}

\section{G. Draught and vertical forces prediction}

Equation (4) and (5) were used to determine furrow opener horizontal and vertical draught forces. The inertia forces were

$H_{\mathbb{E}}=\left[\left(\gamma d^{2} N_{P}+c d N_{\mathbb{Q}}+q d N_{\mathbb{Q}}\right)\left(w+\mathbb{d}\left(m-\frac{1}{3}(m-1)\right)\right)\right] \sin (\mathbb{a}+\delta)$

neglected because, the planter speed was below $10 \mathrm{~km} / \mathrm{h}$, the soil was homogeneous and isotropic [13].

Force $=[($ Soil factors $)($ Implement size $)]$ Direction

$V_{\mathbb{t}}=-\left[\left(\gamma d^{2} N_{\gamma}+\sigma d N_{\mathscr{Q}}+q d N_{\mathbb{Q}}\right)\left(w+d\left(m-\frac{1}{3}(m-1)\right)\right)\right] \cos (\alpha+\delta)$

where, $H_{\mathrm{t}}=$ Draught/horizontal force $(\mathrm{kN}), V_{\mathrm{t}}=$ Vertical Force $(\mathrm{kN}), c=$ Cohesion between soil $\left(\mathrm{kN} / \mathrm{m}^{2}\right), \gamma=$ Density/bulk unit weight of soil $\left(\mathrm{kN} / \mathrm{m}^{3}\right), d=\operatorname{depth}(\mathrm{m}), w=$ width (m), $\mathbb{E}=$ Rake angle (degree), $q=$ Surcharge $\left(\mathrm{kN} / \mathrm{m}^{2}\right)$, $\mathbb{N}_{Q}=$ Gravitational factor, $\mathbb{N}_{G}=$ Cohesion factor, $\mathbb{N}_{\mathbb{Q}}=$ Surcharge factor, $\mathbb{w}^{2}=$ speed $(\mathrm{ms}-1), \delta=$ Interface friction angle (degree), $\mathrm{m}=$ rapture distance.

Determination of ' $\mathrm{N}$ ' factors and rapture distance $(\mathrm{m})$ were obtained from the ' $\mathrm{N}$ ' factor chart, rapture distance and rake angle diagram respectively introduced by [13]. Soil properties used in the analysis (sandy loam) includes density

\section{Number of cups design} used in the design includes depth of opening $0.2 \mathrm{~m}$, width of furrow opener $0.12 \mathrm{~m}$, rake angle $45^{\circ}$ and, tractor speed $\mathrm{km} / \mathrm{h}$. 
The shape factor $(S)$ of the yam sett was determined using equation (6).

$S=100 l 2 w t$

Where $l$ is the length, $w$ the width and $t$ the thickness of the sett in $\mathrm{mm}$, with $t<w<l$

Meanwhile, the number of cups were calculated using equation $(7,8,9)$ adopted from [15]. The distance between cup to cup was assumed to be $34 \mathrm{~cm}$ because the metering mechanism was designed to be driven by the ground wheel which in tend was designed base on the machine's height [16].

$$
\begin{aligned}
& I=\frac{d \mathrm{xt})}{\mathrm{a}} \\
& \mathrm{n}=\frac{\mathrm{d}}{\mathrm{dg}} \\
& \mathrm{C}=\pi \mathrm{xd}
\end{aligned}
$$

where, $I=$ Number of cups; cm; $a$ = cup to cup spacing, speed ratio $(n), D s=$ (No. of teeth on the driver sprocket $d s=$ No. of teeth on driven sprocket, $c=$ circumference of drive wheel, and $d$ is diameter of the wheel.

\section{H. Driving shaft design}

Mild steel AISI 1018 material was used for shaft design because of strength and torsional resistance. Torsional torque transmitted and diameter of a shaft was calculated by using the American Society of Mechanical Engineering (ASME) code in equation (10 and 11) [14]. The Keyway dimension (40 $\times 4 \times 4 \mathrm{~mm}$ ) was provided to fit the sprocket to the shaft to facilitate the movement of the sprocket on the shaft.

The following assumptions were made for the shaft design:

1. For both tension and compression, $84 \mathrm{MPa}$ was used for shafts with a keyway for maximum permissible working stresses.

2. Average shaft speed was $600 \mathrm{rev} / \mathrm{min}^{-1}$, power transmitted by the shaft $(p)=0.02 \mathrm{~kW}$

3. Shaft subjected to combined twisting and bending,

4. Ductile materials such as mild steel was used

5. Material is linearly elastic, or Hook's law is valid

6. There are no internal stresses before loading

7. Load is static

8. The safety factor was 2

$T=\frac{60 \times P}{2 \pi N}$

$d=\frac{3 \sqrt{16 X T}}{\tau \pi}$

Where, $d$ is shaft diameter, $P$ shaft transmitted power, $₫=$ maximum allowable working stress (tensile or compressive) induced due to bending moment, $T=$ Torque transmitted by the shaft and $N=$ Speed of the shaft in revolution per minute (r.p.m).

\section{J. Bearing and chain selection}

The selection of bearing was done by comparing tolerance classifications of national standards. Chain length was calculated using equation 12 adopted from Ranjan [17].

$m=\frac{2 E}{p}+\frac{z_{1}+z_{2}}{2}+\left(Z_{2}-Z_{1}\right)^{2} / 2 \pi p$

Where, $m=$ number of chain links, $C=$ Centre to centre distance between two sprocket, $m, Z_{1}=$ Number of teeth in driver pulley, $Z_{2}=$ Number of teeth in the driven pulley, $P=$ chain pitch (15 mm).

Assumptions

- Low power transmission

- Planting is assumed to be a low-speed operation

- Sprocket of the same size was used for the yam sett conveyor and metering shaft.

\section{K. Bending moment determination}

Shearing forces of a shaft was determined by taking moment at reactions $\left(R_{1}\right.$ and $\left.R_{2}\right)$ and resolve using equation (13) and (14) for resolving reactions [15].

R1 or $\mathbb{R} 2=\frac{W}{2} x$ clochwis

$\mathbb{R}=\frac{w}{2} x-w x+\frac{w}{2} L$

Where $(w)$ is downward load acting on the sprockets, $(\mathrm{L})$ is shaft total length, $(x)$ is distance from fulcr

\section{Mainframe}

Weight and strength were two design factors considered in the determination of the material for the frame. Galvanize Mild steel square pipe of $4.0 \times 4.0 \mathrm{~cm}$ and $4.0 \mathrm{~mm}$ thickness with rigidity and high strength properties were used due to its general engineering purposes [17]

\section{Sett chute}

The location of the sett chute was positioned on the outer part of the hopper by the side on which the cup-chain runs through. Mild steel sheet plate with $1.0 \mathrm{~mm}$ thickness was molded in a channel shape to guide cup-chain of metering mechanism and yam minisett during filling.

\section{N. Ground wheel design}

Wheels were designed for loose soils. The ground wheel diameter was selected based on the machine's height. The design of the width of the wheel was depend on the type of soil and wheel sinkage etc. Assumptions considered were; Ground wheel diameter $(D)$ (height of planter) $=0.8 \mathrm{~m}$ Peripheral distance $=\pi D=2.52 \mathrm{~m}$

Forward speed of planter $=7.2 \mathrm{~km} / \mathrm{h}$

The ground wheel covers $2.52 \mathrm{~m}$ horizontal distance in one revolution, at $7.2 \mathrm{~km} / \mathrm{h}$. Flat bar thickness of $3 \mathrm{~mm}$ was rolled to form a circle of $40 \mathrm{~cm}$ diameter to form a driving wheel. Sixteen $(16 \mathrm{~mm})$ iron rods were attached alternately throughout the circumference of the wheel to provide lugs for effective gripping of the ground surface. The arrangement of $16 \mathrm{~mm}$ iron rod across the inner diameter of the wheel served as spokes. The spokes were joined to a hub containing a bearing for a shaft to run through to withstand the torsional moment.

\section{O. Planter power requirement}

The tractor selection for pulling (DRYM) planter was based on the assumption that drawbar horse power (DBHP) of the tractor is about $70 \%$ of engine brake horse power (BHP) W of its engine when the machine is in good condition [18].

\section{RESULTS AND DISCUSSION}

\section{A. Furrow opener, ridger bottom and hopper result}

Figure 3 presents the effect of furrow opener rake angle on draught and vertical force. The mean draught (horizontal) and vertical forces on the furrow opener were 2.41 and $-0.95 \mathrm{kN}$, respectively. The predicted forces imply that low horse power tractor such as category I (50 W) was able to pull the planter. The negative value indicates that furrow opener was able to penetrate in the soil. There was an increased rake angle with increasing draught and vertical forces.

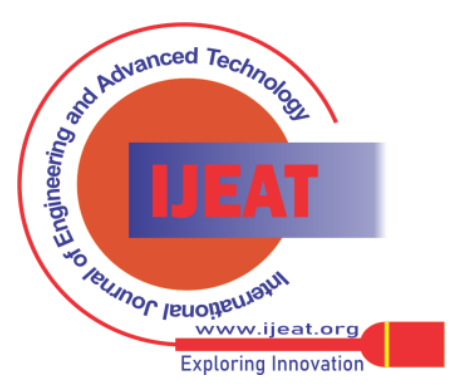


The result was in agreement with [14] that, to achieve a small draught force and penetration, implements must be designed with a small rake angle.

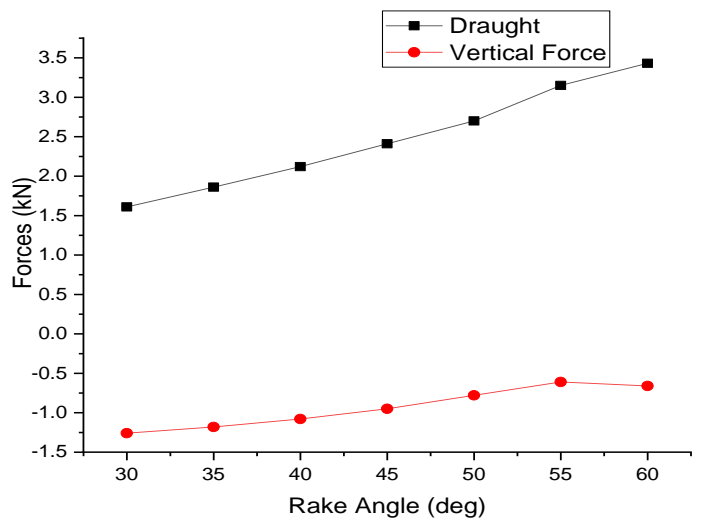

Fig. 3: Effect of rake angle on draught and vertical force

The furrow opener total deformation, equivalent (Von-Mises) stress, and maximum directional deformation (x-axis) results were $0.002 \mathrm{~mm}, 6.27 \mathrm{MPa}$ and $0.0009 \mathrm{~mm}$ respectively. All these values were below the deformation, equivalent (Von-Mises) stress and directional deformation of $50 \mathrm{~mm}, 250 \mathrm{MPa}$ and $20 \mathrm{~mm}$, respectively of the selected furrow opener material (A36 structural steel). Recorded stress and deformation values were concentrated between shares and wings, and at the shares (tip) of the furrow opener respectively. This indicates that the furrow opener model was below structural steel specification used for deformation (50 $\mathrm{mm})$, equivalent (Von-Mises) stress (250 $\mathrm{MPa})$ and directional deformation (20 mm)

Again, ridger bottom total deformation, equivalent (Von-Mises) stress, and maximum directional deformation

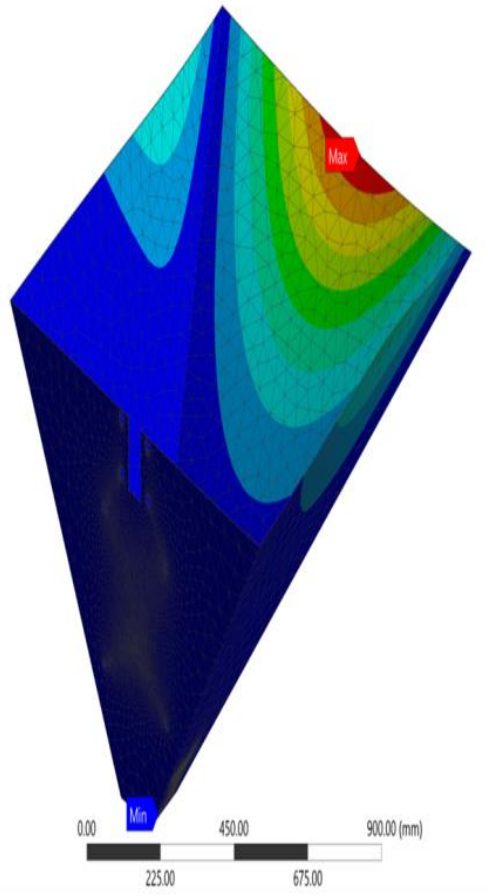

(x-axis) results were $0.01 \mathrm{~mm}, 9.18 \mathrm{MPa}$ and $6.20 \mathrm{~mm}$, respectively. The values were below the deformation, equivalent (Von-Mises) stress and directional deformation 50 $\mathrm{mm}, 250 \mathrm{MPa}$ and $20 \mathrm{~mm}$ ), respectively of the selected ridger bottom material (A36). The higher stress and deformation values $(9.18 \mathrm{MPa})$ and $(0.01 \mathrm{~mm})$ respectively were concentrated at the shares and wings (tip) of the ridger bottom. Simulation results suggest that the ridger bottom model was within the acceptable design and permissible stress limits of structural steel (A36) used because deformation, equivalent (Von-Mises) stress and directional deformation recorded were below the properties of the structural steel used $50 \mathrm{~mm}, 250 \mathrm{MPa}$ and $20 \mathrm{~mm}$, respectively.

Total deformation, equivalent (Von-Mises) stress, magnitude, and force concentration on hopper, furrow opener and ridger bottom of the planter were presented in Fig. 4, 5 and 6. Fig. (4a) was the total deformation (meshed) contour plot for hopper and (4b) was the total deformation contour plot, Fig. (5a) was the total deformation (meshed) contour plot furrow opener and Fig. (5b) was the total deformation contour plot. Whereas Fig. 6 was the total deformation (meshed) contour plot for ridger bottom and Fig. 6b was the total deformation contour plot-ridger bottom. Total deformation, equivalent (Von-Mises) stress, and maximum directional deformation (y-axis) were $0.44 \mathrm{~mm}, 7.37 \mathrm{MPa}$ and $0.08 \mathrm{~mm}$ respectively. Stress and deformation values of $7.37 \mathrm{MPa}$ and $0.44 \mathrm{~mm}$ respectively were concentrated at the top side of the hopper, which suggests that loading of minisett should not go beyond the point at a higher concentration for the hopper to withstand anticipated stress and deformation without deteriorating.
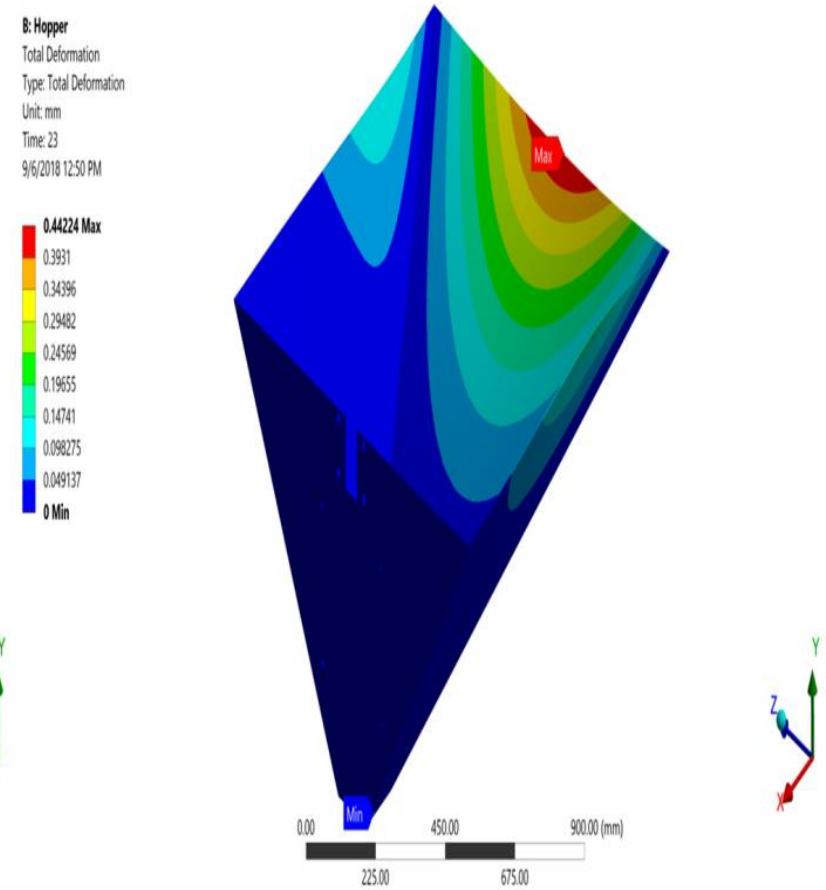

Fig. 4a. Total deformation (meshed) contour plot- hopper, b) Total deformation contour plot
Published By:

Blue Eyes Intelligence Engineering and Sciences Publication (BEIESP) 77 (C) Copyright: All rights reserved.

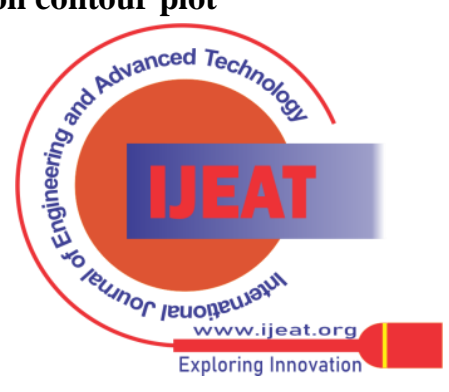



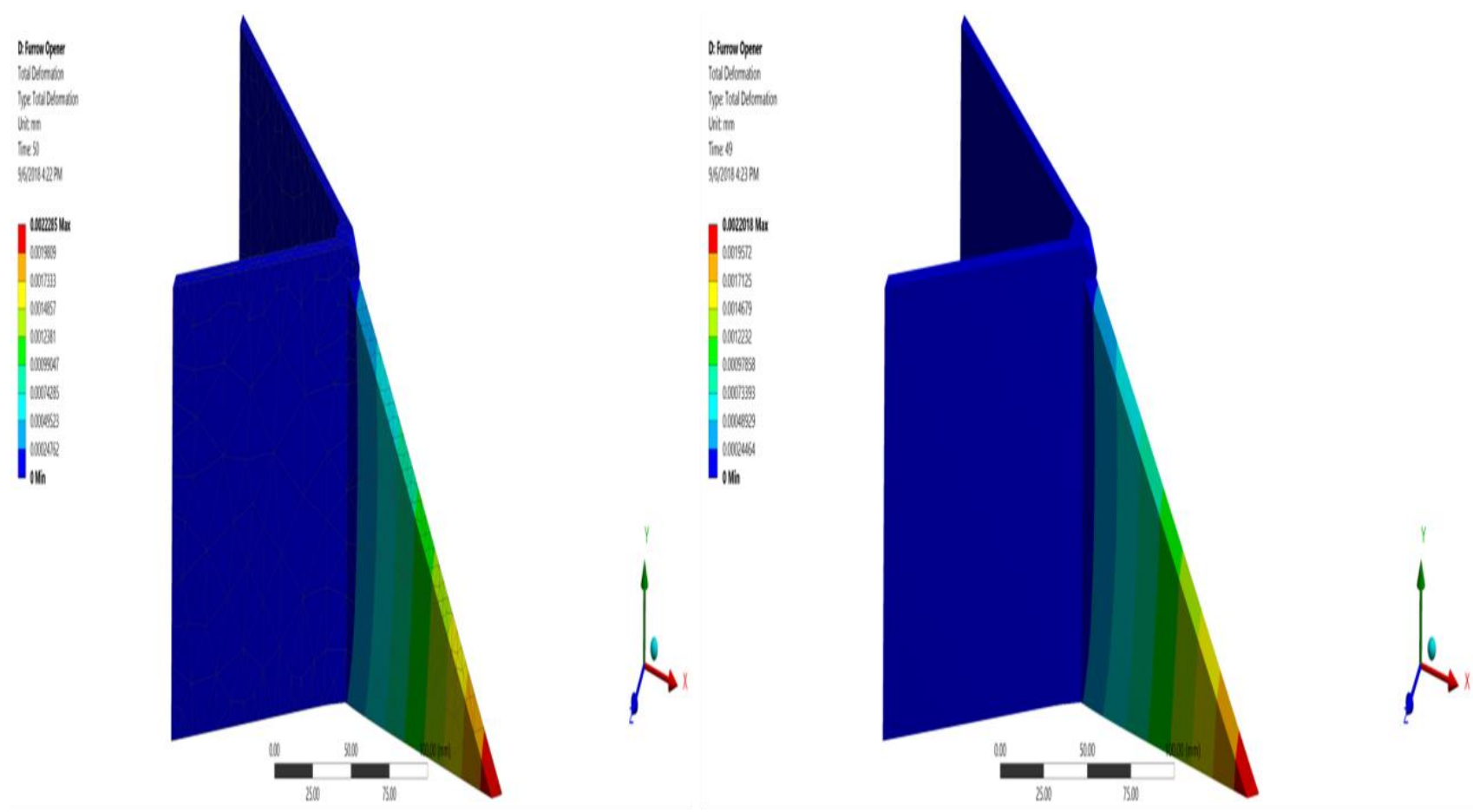

Fig. 5a. Total deformation (meshed) contour plot- furrow opener, 5b) Total deformation contour plot
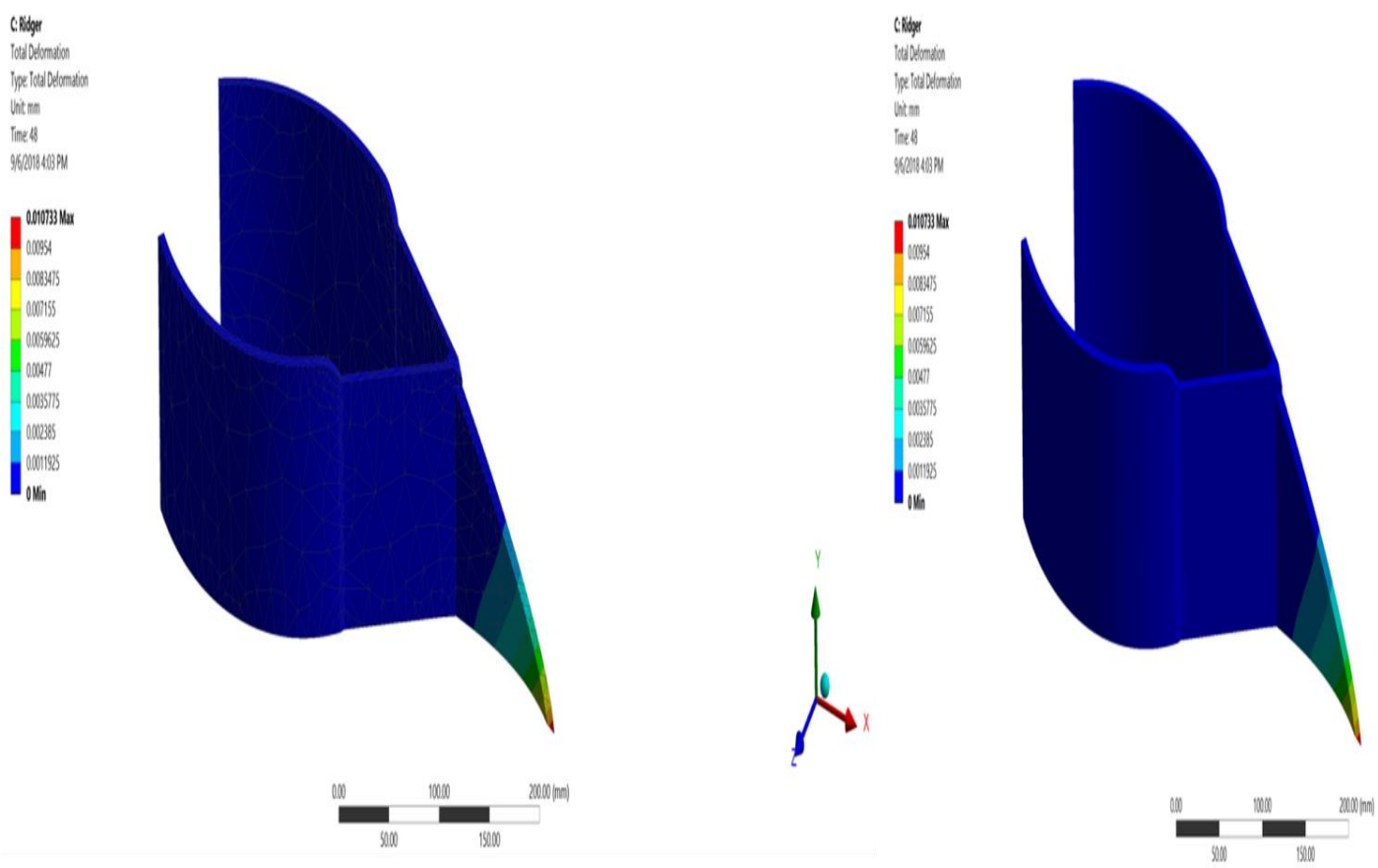

Fig. 6a. Total deformation (meshed) contour plot- ridger bottom, 6b) Total deformation contour plot

The general result suggests that the hopper model values were lower per design and material specifications for deformation (50 mm), equivalent (Von-Mises) stress (440 MP) and directional deformation $(25 \mathrm{~mm})$ of the selected hopper material AISI 1018. Hence the design of hopper was safe to use because [19] reported that high stress and deformation values have a shorter operational life cycle as a result of high wear and fatigue rate. Total deformation, equivalent (Von-Mises) stress, magnitude, and force concentration on the whole planter was presented in Fig. 7 (a) and (b). Total deformation shown in Fig. 7a was 15.93 $\mathrm{mm}$ against $(50 \mathrm{~mm}$ ) whereas equivalent (Von-Mises) stress presented in Fig. 7b was $75.37 \mathrm{MPa}$ against (250, $440 \mathrm{MPa}$ ) of mild and structural steel respectively. The entire FEA result for the planter suggests that planter assembly was designed within the safe boundaries, because deformation, equivalent (Von-Mises) stress and directional deformation recorded for respective components were below the properties of the material used.

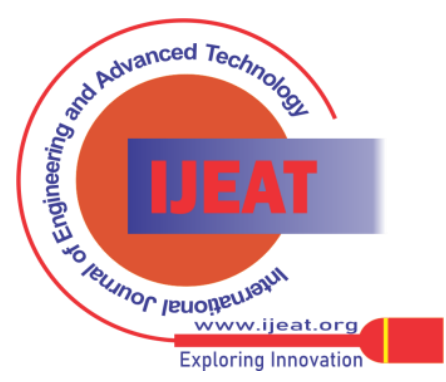




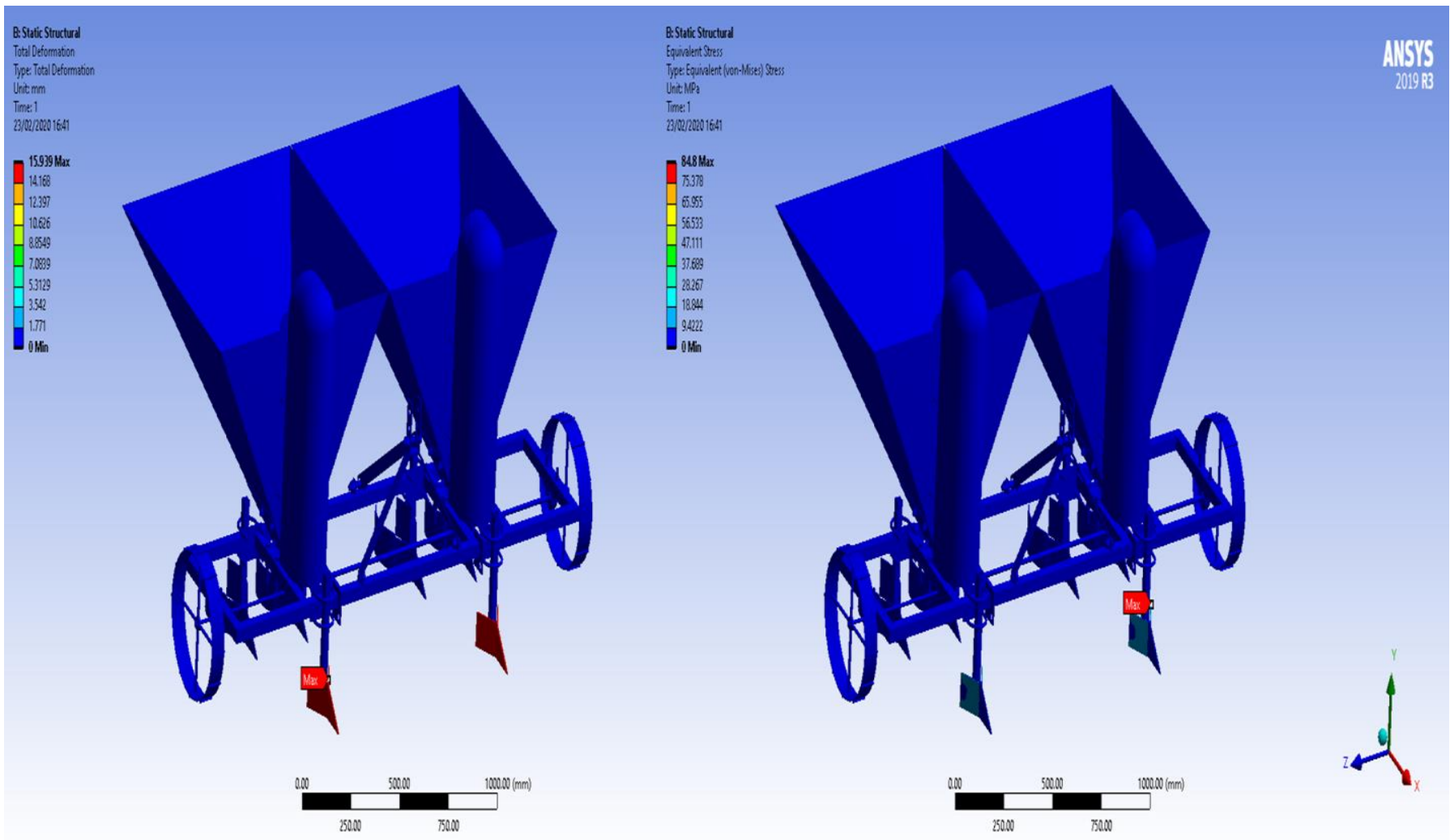

Fig. 7a. Total deformation,

Fig. 7b) Equivalent (Von-Mises) contour plot

\section{B. Number of cups, ground wheel and driving shaft}

The cup and wheel for planter metering mechanism were presented in Fig. 8a and 8b. Fig. 8a was the cup for metering mechanism while Fig. 8b was the ground wheel for the planter. The metering mechanism consist of 5 number of cups at $35 \mathrm{~cm}$ interval and circumference of the drive shaft was $194.8 \mathrm{~cm}$. Seed metering was cup-chain. Also, mild steel

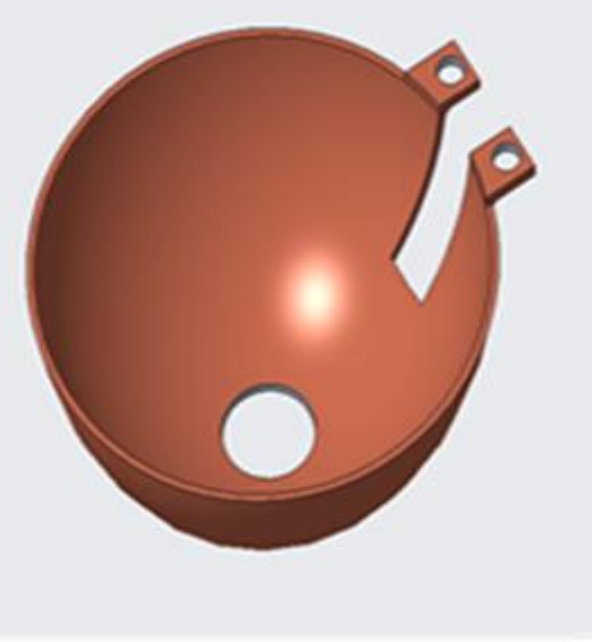

Fig. 8a. Cup for metering and

\section{Figure 8: Cup for metering and Ground wheel}

Comparing tolerance classifications of national standards were considered 7026T1 for bearing; thrust load was $2 \mathrm{kN}$, speed: $5000 \mathrm{rev} / \mathrm{min}^{-1}$, lubrication: grease and run time: $50 \mathrm{~h}$ (ISO standards and JIS B 1514). The pictorial and $3^{\text {rd }}$ angle projection drawing were shown in Fig. 9 (a) and (b), respectively. shaft of $25 \mathrm{~mm}$ diameter of mass $5 \mathrm{~kg}$ was used as transmission shaft whiles $3.18 \mathrm{kNm}$ torsional torque was transmitted by the shaft. Loads supported by bearing at reactions $\left(R_{1}\right.$ and $\left.R_{2}\right)$ were $69 \mathrm{kN}$ at each supported end of the shaft. The design implies that loading beyond the calculated load may bend the shaft and fail.

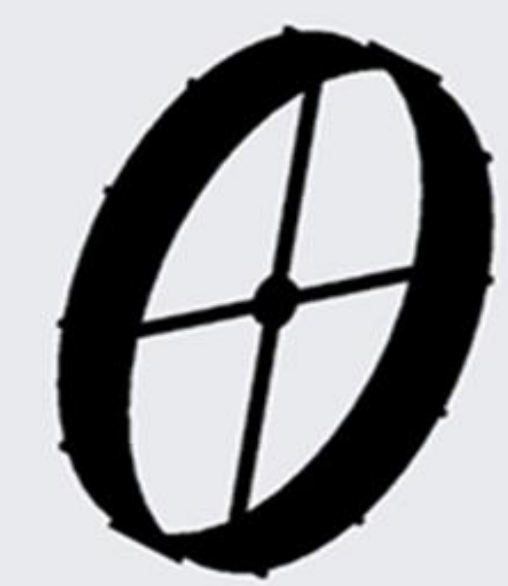

8b. Ground wheel for the planter

Published By:

Blue Eyes Intelligence Engineering and Sciences Publication (BEIESP) C Copyright: All rights reserve

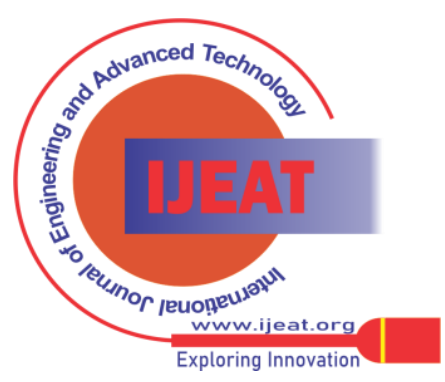




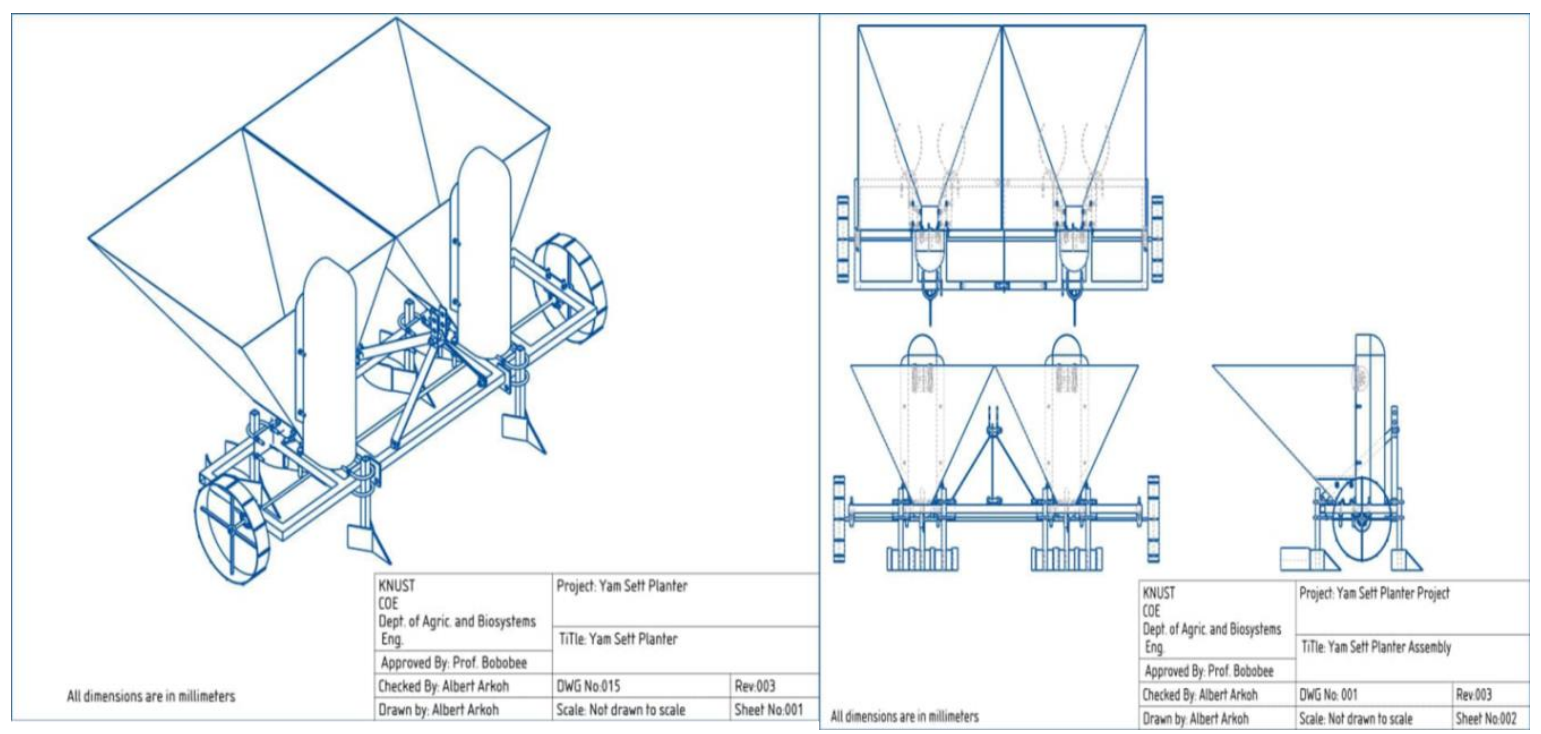

Fig. 9a: Planter Pictorial Drawing; 9b, Planter $3^{\text {rd }}$ Angle Projection

\section{Tractor requirement to pull DRYM planter}

Drawbar Horsepower (DBHP) of tractor was $35 \mathrm{~kW}$, and the size of the tractor required to pull the DRYM planter was category I of $50 \mathrm{hp.} \mathrm{Fig.} 10$ presets finished yam planter coupled to the tractor.

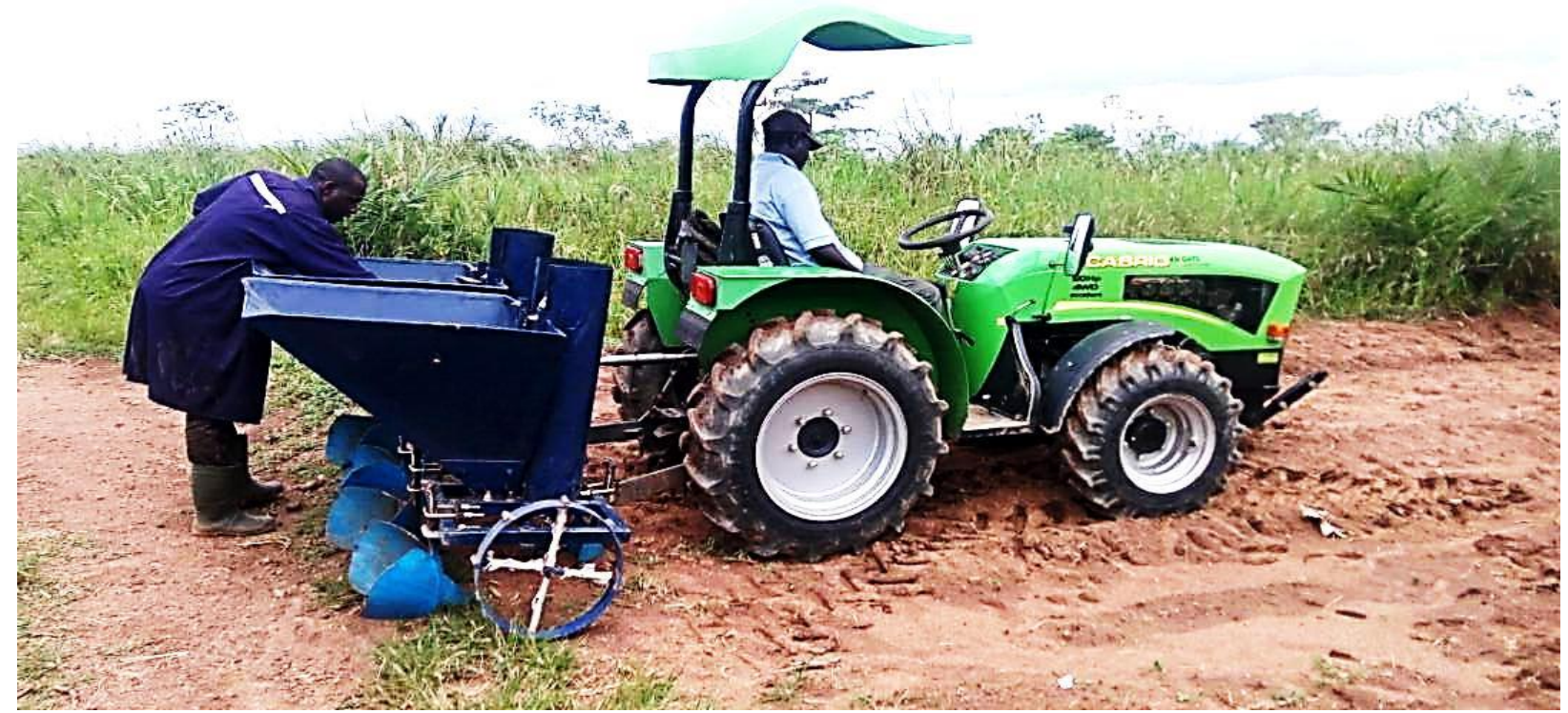

Fig. 10: DRMM planter Hitch to Category I Tractor during field trials

\section{CONCLUSION}

The minisett yam planter has been developed with the following specifications: length, width, height as $177 \times 54 \times$ $130 \mathrm{~cm}$ and a weight of $120 \mathrm{~kg}$. The predicted horizontal draught and vertical forces on the furrow opener were 2.41 and $-0.95 \mathrm{kN}$, respectively. Further studies should focus on determining the field draught on the planter to validate the predicted forces to establish the real condition of loads acting on the planter.

\section{ACKNOWLEDGMENT}

The authors wish to express their profound gratitude to Prof. Otto of the CSIR-Crops Research Institute and the entire staff of Takoradi Technical University, Department of Automotive and Refrigeration Engineering.

\section{REFERENCES}

1. FAOSTAT. FAO Statistical Yearbook. Food and Agriculture Organization of the United Nations Statistics Rome, Italy; 2016. Retrieved from http://www.fao.org/faostat/en/\#data/QC.

2. FAO. FAO Statistical Yearbook: World Food and Agriculture; 2013. Retrieved from http://www.fao.org/docrep/018/13107e00.htm

3. J. Bergh and J. Löfström. Interpolation spaces: an introduction, Springer Science \& Business Media. 2012

4. J. Awulu and I. Itodo. Umogbai V. Effect of Tractor Forward Speed on Metering Efficiency and Evenness of Planting of a Device for Mechanized Yam Sett Planting. The International Journal of Engineering and Science (IJES). 2013; 2(5), 61-67.

Published By:

Blue Eyes Intelligence Engineering and Sciences Publication (BEIESP)

80 (c) Copyright: All rights reserved.

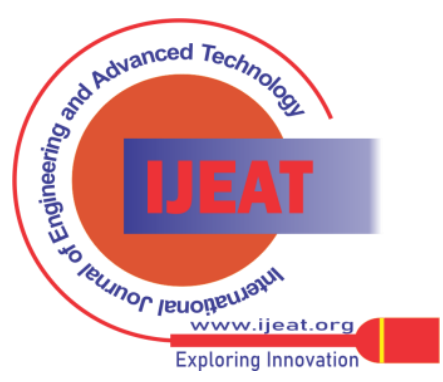


5. C. K. Bosrotsi, A. Addo, A. K. Dzisi and S. K. Agodzo. Development of a Yam Harvester using Finite Element Method. International Journal of Modern Studies in Mechanical Engineering (IJMSME). 2017a 3 (1), 35-44.

6. H. Buitenwerf, W. Hoogmoed, P. Lerink and J. Müller. Assessment of the Behaviour of Potatoes in a Cup-belt Planter. Biosystems engineering. 2006; 95; 35-41.

7. K. A. AL-GAADI AND S. A. MAREY. EFFECT OF FORWARD SPEED AND TUBER CHARACTERISTICS ON TUBER SPACING UNIFORMITY FOR A CUP-BELTPOTATO PLANTER. MIDDLE-EAST JOURNAL OF SCIENTIFIC RESEARCH. 2011; 8(4): PP 753-758.

8. A. K. Arkoh and E. Y. H. Bobobee. Effect of planting depth and orientation germination of yam (Dioscorea) minisett. Internationa Journal for Research in Applied Science and Engineering Technology (IJRASET). 2018; 6 (6).

9. S. Gu, S. Wu, L. Cao, M. Li, N. Qin, Z. Zhu, Z. Wang, Y. Li, Z. Li and J. Chen . Tunable Redox Chemistry and Stability of Radical Intermediates in 2D Covalent Organic Frameworks for High Performance Sodium Ion Batteries. Journal of the American Chemical Society. 2019.

10. O. Ani, B. Uzoejinwa, and N. Anochili. Design, construction and evaluation of a vertical plate maize seed planter for gardens and small holder farmers. Nigerian Journal of Technology. 2016; 35, 647-655.

11. A. G. Adeogun, B. A. Ibitoye, A. Salami and G. T. Ihagh. Sustainable management of erosion prone areas of upper watershed of Kainji hydropower dam, Nigeria. Journal of King Saud University-Engineering Sciences. 2020; 32, 5-10.

12. R. J. Godwin and M. J. O'dogherty. Integrated soil tillage force prediction models. Journal of Terramechanics. 2006; 44, 3-14.

13. D. R. P. Hettiaratchi and A. R. Reece. Symmetrical three-dimensional soil failure. Journal of Terramechanics. 1074; 4, 45-67.

14. R. Godwin and G. Spoor. Soil failure with narrow tines. Journal of Agricultural Engineering Research. 1977; 22, 213-228.

15. R. K. Ningthoujam, H. Balzter, K. Tansey, K. Morrison, S. Johnson, F. Gerard, C. George, Y. Malhi, G. Burbidge, and S. Doody. Airborne S-band SAR for forest biophysical retrieval in temperate mixed forests of the UK. Remote Sensing. 2016; 8, 609.

16. D. N. Sharma, and S. Mukesh. Farm Machinery Design Principle and Problems. 3rd. Edition, Jain Brothers, New Delhi. 2013.

17. S. Ranjan. Machine learning based botnet detection using real-time extracted traffic features. Google Patents. 2014.

18. M. Naderi, R. Alimardani, R. Abbaszadeh and H. Ahmadi. Assessments of dynamic load equations through drive wheel slip measurement. American-Eurasian Journal of Agriculture \& Environmental Science, 2008; 3, 778-784.

19. B. R. Goodman, M. K. Hunsaker, D. M. Newton, Y. N. Liu, E. M. Sabbagh, R. A. Sprague and Y. M. Fradkin. Resolving configuration conflicts using a multi-valued decision diagram. Google Patents. 2019

\section{AUTHORS PROFILE}

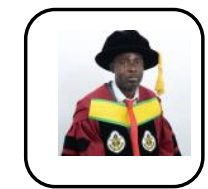

A. K. Arkoh (Ph. D), from Kwame Nkrumah University of Science and Technology (KNUST) Kumasi, Ghana, Department of Agricultural and Biosystems Engineering and currently lecture at Takoradi Technical University, Department of Automotive and Refrigeration Engineering.

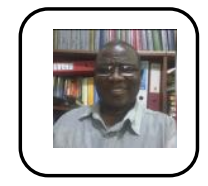

E. Y. H. Bobobee, an Associate Professor at Kwame Nkrumah University of Science and Technology. (KNUST) Kumasi, Ghana, Department of Agricultural and Biosystems Engineering

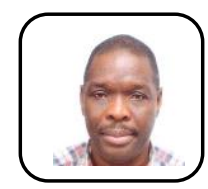

A. Addo, A Professor at Kwame Nkrumah University of Science and Technology. (KNUST) Kumasi, Ghana, currently lecture at KNUST, Department of Agricultural and Biosystems Engineering.

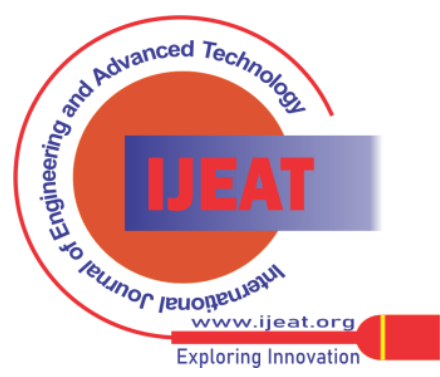

